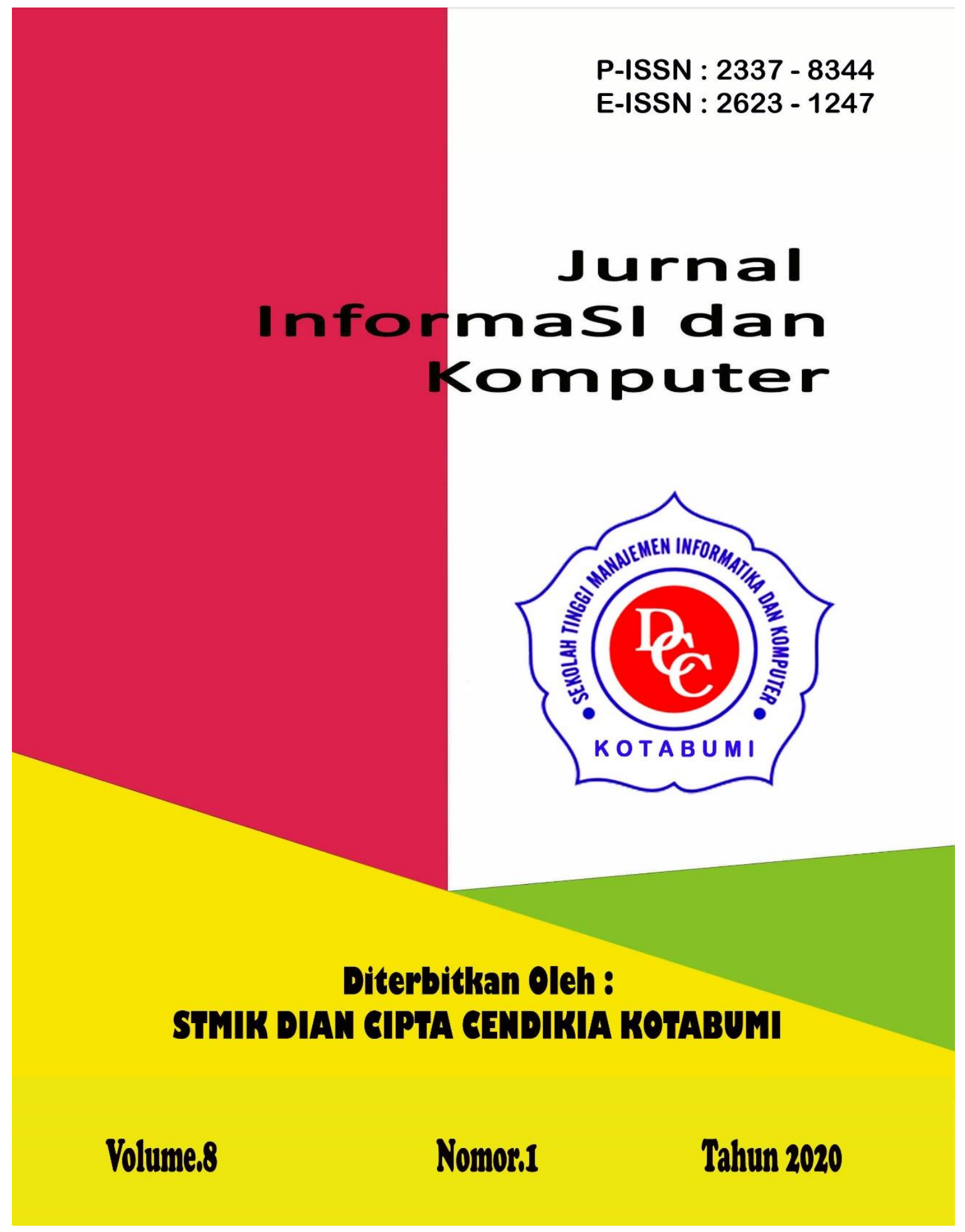


Penerbit:

STMIK DIAN CIPTA CENDIKIA KOTABUMI

Bekerjasama dengan LPPM STMIK DCC Kotabumi

Hak atas naskah/tulisan tetap berada pada penulis, isi diluar tanggung jawab

Penerbit dan Dewan Penyunting

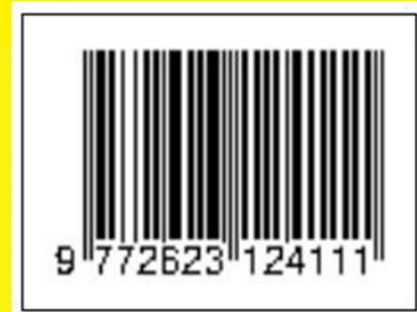




\section{PENGANTAR REDAKSI}

Puji syukur dipanjatkan kehadirat Tuhan Yang Maha Esa, atas karunia dan limpahan rahmatNYA jualah Jurnal Informatika dan komputer (InfoKom) STMIK Dian Cipta Cendikia Kotabumi ini dapat terwujud.Jurnal Informatika dan Komputer (InfoKom) yang terbit dua (2) kali dalam setahun ini merupakan suatu wadah untuk penyebar luasan hasil-hasil penelitian, studi pustaka, karya ilmiah yangberkaitan dengan Informatika dan Komputer khususnya bagi dosen-dosen STMIK Dian Cipta Cendikia Kotabumi serta umumnya para cendikiawan, praktisi, peneliti ilmu Informatika dan Komputer.

Harapan, dengan diterbitkannya Jurnal Informatika dan Komputer (InfoKom) ini sebagai salah satu bentuk sumbangan pemikiran dalam pengembangan ilmu informatika dan komputer yang berkaitan dengan kajian-kajian di bidang tekhnologi Informatik, Komunikasi Data dan Jaringan Komputer, perancangan dan Rekayasa Perangkat Lunak, serta ilmu-ilmu yang terkait dengan bidang Informatika dan Komputer lainnya.

Berkenaan dengan harapan tersebut, kepada para peneliti, dosen dan praktisi yang memiliki hasil-hasil penelitian, kajian pustaka, karya ilmiah dalam bidang tersebut diatas, dengan bangga redaksi Jurnal Informatika dan Komputer (JIK) menerima naskah ringkasan untuk dimuat pada jurnal Informatika dan Komputer (InfoKom) STMIK Dian Cipta Cendikia Kotabumi dengan berpedoman pada penulisan naskah jurnal sebagaimana dilampirkan pada halaman belakang (Bagian kulit dalam) buku jurnal ini.

Mutu dari suatu jurnal ilmiah tidak hanya ditentukan oleh para pengelolanya saja, tetapi para penulis dan pembaca jualah yang mempunyai peranan besar dalam meningkatkan mutu jurnal Informatika dan Komputer ini. Merujuk pada realita ini kamu sangat mengharapkan peran aktif dari peneliti untuk bersama-sama menjaga dan memelihara keberlangsungan dari jurnal Informatika dan Komputer STMIK Dian Cipta Cendikia Kotabumi ini. Yang juga tidak kalah pentingnya dari partisipasi tersebut diatas, adalah saran dan kritik yang membangun dari pembaca yang budiman agar kiranya dapat disampaikan langsung kepada redaksi JIK. Saran dan kritik yang membangun akan dijadikan masukan dan pertimbangan yang sangat berarti guna peningkatan mutu dan kualitas Jurnal Informatika dan Komputer STMIK Dian Cipta Cendikia Kotabumi.

Tak lupa diucapkan terima kasih yang tak terhingga atas perhatian dan kerjasama dari semua pihak yang tak dapat disebutkan satu persatu hingga dapat diterbitkan nya Jurnal Informatika dan Komputer (InfoKom) STMIK Dian Cipta Cendikia Kotabumi. Semoga apa yang telah diperbuat untuk kebaikan akan menjadi amal ibadah, amin.

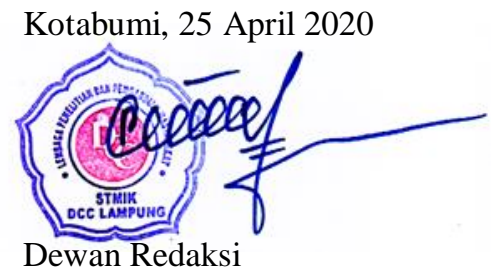




\section{JURNAL INFORMASI DAN KOMPUTER}

Volume 8 Nomor 1 April 2020

Jurnal Informasi dan Komputer merupakan Sarana informasi ilmu pengetahuan, Tekhnologi dan Komunikasi yang berupa hasil penelitian, tulisan ilmiah, Ataupun studi pustaka. Jurnal ini terbit dua kali setahun pada bulan April dan Oktober. Berisi hasil penelitian ilmiah di bidang informatika yang bertujuan untuk menghubungkan adanya kesenjangan antar kemajuan teknologi dan hasil penelitian. Jurnal ini di terbitkan pertama kali pada tahun 2013.

Penanggung Jawab:

Ketua STMIK Dian Cipta Cendikia

Kotabumi

\section{Pembina:}

Ketua STMIK Dian Cipta Cendikia

Kotabumi

Ketua Lembaga Penelitian STMIK Dian

Cipta Cendikia Kotabumi

\section{Pimpinan Redaksi}

Dwi Marisa Efendi,.S.Kom.,M.Ti

\section{Redaksi pelaksana}

Rustam,.S.Kom,.M.Ti (STMIK Dian

Cipta Cendikia Kotabumi)

Nurmayanti M.Kom (STMIK Dian

Cipta Cendikia Kotabumi)

Sukatmi,.S.Kom., M.Kom (AMIK DCC

Bandar Lampung)

Sampurna Dadi Riskiono,M.Kom

(Universitas Teknokrat Indonesia)

Ifo Wahyu

Pratama,S.Kom.,M.Ti(AMIK MASTER

Lampung)

\section{Mitra Bestari}

Merri Parida.,M.Kom (STMIK Dian

Cipta Cendikia Kotabumi)

Amarudin,S.Kom.,M.Eng (Universitas

Teknokrat Indonesia)

Didi Susianto.,S.T.,M.Kom (AMIK

DCC Bandar Lampung)

Alhibarsyah.,S.T.,M.Kom (Stmik Tunas

Bangsa Bandar Lampung)

Kemal Farouq Mauladi

.,S.Kom.,M.Kom (Universitas Islam

Lamongan)

Agus Setiawan S.Pd.,M.Eng

(Universitas Muhammadiyah

Lamongan)

Penerbit : STMIK Dian Cipta Cendikia Kotabumi Bekerja Sama Dengan LPPM STMIK Dian Cipta Cendikia Kotabumi.

\section{Alamat Redaksi/Penerbit:}

Jl. Negara No. 3 Candimas Kotabumi

Lampung Utara

No Telpon/Fax 072423003

Email :1ppm-stmik@dcc.ac.id 


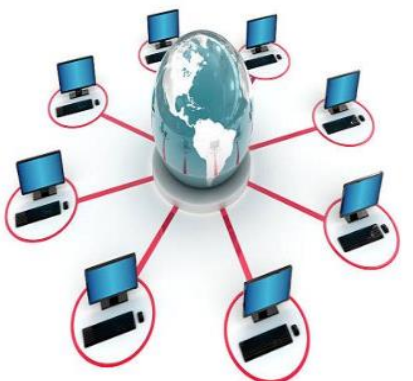 \\ JURNAL INFORMASI DAN KOMPUTER VOL. 8 NO. 1 THN. 2020}

\section{DAFTAR ISI}

\section{Halaman}

Sistem Pendukung Keputusan Penentuan Lahan Kopi Terbaik Dengan Metode

Ahp (Analytic Hierarchy Process)

Sidik Rahmatullah, Rendy Abdurahman (AMIKKOM Jogja,

STMIK Dian Cipta Cendikia Kotabumi)

Rancang Bangun Sistem Informasi Pada Program Pembangunan Pemberdayaan

Masyarakat Desa( P3md ) Berbasis Web Mobile

Ferly Ardhy, Firmansyah, Sidik Rahmatullah,(IIB Darma Jaya Bandar Lampung

STMIK Dian Cipta Cendikia Kotabumi, AMIKKOM Jogja)

Sistem Informasi Pengolahan Data Alumni Sekolah Menengah Atas (Sma)

Merri Parida, Nindiya Ova Rahmawati (AMIKKOM Jogja,

STMIK Dian Cipta Cendikia Kotabumi)

SISTEM INFORMASI GEOGRAFIS PUSKESMAS BESERTA SARANA

DAN PRASARANA BERBASIS WEB MOBILE

Nurmayanti, Windy Dwi Bahari (AMIKOM Jogja,

STMIK Dian Cipta Cendikia Kotabumi)

Rancang Bangun Sistem Informasi Konseling Untuk Sekolah Menengah Kejuruan

(Smk) Berbasis Website

Aliy Hafiz1, Galih Rakasiwi, Ifo Wahyu Pratama, Agus Komarudin,

Bambang Suparapto, Fathurrahman Kurniawan Ikhsan

(AMIK Dian Cipta Cendikia Bandar Lampung,

Universitas Nahdhatul Ulama Lampung, AMIK Dian Cipta Cendikia Pringsewu,

Universitas Mitra Indonesia, Lampung) .....

Sistem Pendukung Keputusan Pemilihan Driver Terbaik Menggunakan Metode

Weight Product (Wp)

Dina Lorenza, Pitrawati (STMIK Dian Cipta Cendikia Kotabumi

AMIK Dian Cipta Cendikia)

Rancang Bangun Sistem Informasi Pembayaran Mahasiswa

Darsin(Universitas Megou pak Tulang Bawang)

Sistem Informasi Geografis Bengkel Motor Honda Resmi Bandar Lampung

Sukatmi, Nuraini (AMIK Dian Cipta Cendikia Bandar Lampung).....

Sistem Pakar Diagnosa Penyakit Kulit Wajah Dengan Metode

Certainty Factor Pada Klinik Skin Rachel

Dwi Marisa Efendi, Putri Yulita Sari (IIB Darmajaya Bandar Lampung,

STMIK Dian Cipta Cendikia Kotabumi) 
Sistem Informasi Monitoring Siswa Pada Mts Al-Islamiah Bunut Kabupaten Pesawaran Yuli Syafitri ${ }^{2}$, Reni Astika ${ }^{1}$, Septian Hernando $^{3}$ AMIK Dian Cipta Cendikia

Aplikasi Kamus Bahasa Jepang Berbasis Mobile Android

Rustam $^{2}$, A Yanda Febry Pangestu ${ }^{2}$ Sistem Informasi, Teknologi Komputer ${ }^{1}$, IIB Darmajaya

Bandar Lampung ${ }^{2}$ STMIK Dian Cipta Cendikia Kotabumi 


\title{
SISTEM INFORMASI GEOGRAFIS PUSKESMAS BESERTA SARANA DAN PRASARANA BERBASIS WEB MOBILE
}

\author{
Nurmayanti ${ }^{1}$, Windy Dwi Bahari ${ }^{2}$ \\ Sistem Informasi ${ }^{1}$, Sistem Informasi ${ }^{2}$ \\ STMIK Dian Cipta Cendikia Kotabumi ${ }^{12}$ \\ Jl. Negara no. 03 Candimas Kotabumi Lampung Utara Kodepos.34581 \\ E-Mail : nurmayanti89@gmail.com ${ }^{1}$,windibahari95@gmail.com²
}

\begin{abstract}
ABSTRAK
Puskesmas sangatlah dibutuhkan bagi masyarakat pada umumnya, apalagi saat sekarang ini biaya pengobatan sangatlah mahal bagi sebagian besar masyarakat. Untuk itulah diperlukan pilihan sarana kesehatan yang terjangkau seperti puskesmas. Seringkali banyak lokasi puskesmas dan sarana prasarana nya yang belum diketahui masyarakat secara luas dan tidak diimbangi informasi.

Dalam hal ini untuk merancang Sistem Informasi Geografis (SIG) untuk dapat mengetahui lokasi puskesmas beserta sarana prasarana nya. Dalam perancangan dan pengembangan aplikasi, digunakan Extreme Programming dan sumber data yang digunakan dalam penelitian ini yaitu Peta Kabupaten Lampung Utara yang diperoleh dari Google Maps API.

Hasilnya adalah adanya satu aplikasi system yang dapat dioperasikan oleh masyarakat luas dengan tujuan untuk mengetahui letak puskesmas beserta sarana prasarana nya yang berada di Kabupaten Lampung Utara.Sehingga masyarakat dapat lebih mudah mengetahui lokasi puskesmas beserta sarana prasarana nya hanya dengan menggunakan keyword untuk pencarian lokasi puskesmas. Sistem Informasi geografis ini dapat mengetahui jalan yang harus dilewati menuju puskesmas dan mengetahui sarana prasarana apa saja yg terdapat di puskesmas tersebut
\end{abstract}

Kata Kunci : GIS Puskesmas, Lokasi, Dinas Kesehatan

\section{ABSTRACTS}

Puskesmas are needed for the community at large, especially now that medical costs are very expensive for most people. For this reason, an affordable choice of health facilities such as puskesmas is needed. Often many puskesmas locations and infrastructure facilities are not widely known and are not balanced by information.

In this case to design a Geographic Information System (GIS) to be able to find out the location of the health center and its infrastructure. In designing and developing applications, Extreme Programming is used and the data source used in this study is the North Lampung Regency Map obtained from the Google Maps API.

The result is an application system that can be operated by the wider community with the aim to find out the location of the puskesmas and its infrastructure in North Lampung District. So that the community can more easily find out the location of the puskesmas and its infrastructure only by using keywords to search for the puskesmas location. This geographical information system can know the road that must be passed to the puskesmas and know what infrastructure facilities are in the puskesmas

Keywords: GIS Puskesmas, Location, Health Office

\section{PENDAhuluan}


Teknologi Informasi dan Komunikasi telah berkembang sangat jauh saat ini dan telah merevolusi cara hidup kita, baik terhadap cara berkomunikasi, cara belajar, cara bekerja, cara berbisnis, dan lain sebagainya. Era informasi memberikan ruang lingkup yang sangat besar untuk mengorganisasikan segala kegiatan melalui cara baru, inovatif, instan, transparan, akurat, tepat waktu, lebih baik, memberikan kenyamanan yang lebih dalam mengelola dan menikmati kehidupan. Dengan teknologi informasi dan komunikasi semua proses kerja dan konten akan ditransformasikan dari fisik dan statis menjadi digital, mobile, virtual dan personal. Akibatnya kecepatan kinerja bisnis meningkat dengan cepat. Kecepatan proses meningkat sangat tajam di banyak aktivitas modern manusia.

Informasi lokasi puskesmas beserta sarana dan prasarana yang dimiliki merupakan salah satu hal penting yang harus di ketahui oleh masyarakat. Lokasi puskesmas dan sarana prasarana yang tersebar di Kabupaten Lampung Utara memiliki informasi yang berhubungan dengan data spasial dan non spasial, seperti nama dan alamat (lokasi) yang berkaitan dengan fasilitas tersebut. Informasi-informasi ini pastinya dibutuhkan oleh berbagai pihak khususnya masyarakat di Kabupaten Lampung Utara.

Keberadaan lokasi puskesmas dan sarana prasarana di Kabupaten Lampung Utara tersebar cukup merata di berbagai tempat. Seringkali banyak lokasi puskesmas dan sarana prasarana yang belum diketahui masyarakat secara luas dan tidak diimbangi informasi, sehingga masih banyak masyarakat Kabupaten Lampung Utara yang tidak mengetahui dimana saja lokasi puskesmas sehingga masyarakat di Kabupaten Lampung Utara mengetahui jarak puskesmas dari lokasi masyarakat tersebut berada.

\section{METODELOGI PENELITIAN}

\subsection{Metode Pengembangan Sistem}

Adapun tahapan pada

Extreme Programming dapat di jelaskan sebagai berikut:

\subsubsection{Planning / Perencanaan}

Pada tahap perencanaan ini dimulai dari pengumpulan kebutuhan yang membantu tim teknikal untuk memahami konteks bisnis dari sebuah aplikasi. Selain itu pada tahap ini juga mendefinisikan output yang akan dihasilkan, fitur yang dimiliki oleh aplikasi dan fungsi dari aplikasi yang dikembangkan.

\subsubsection{Design / Perancangan}

Metode ini menekankan desain aplikasi yang sederhana, untuk mendesain aplikasi dapat menggunakan Class-ResponsibilityCollaborator (CRC) cards yang mengidentifikasi dan mengatur class pada object-oriented.

\subsubsection{Coding / Pengkodean}

Konsep utama dari tahapan pengkodean ada extreme programming adalah Pairprogramming, melibatkan lebih dari satu orang untuk menyusun kode.

\subsubsection{Testing / Pengujian}

Pada tahapan ini lebih fokus pada pengujian fitur dan fungsionalitas dari aplikasi. Seiring dengan banyaknya pendatang yang ada di Kabupaten Lampung Utara yang masih awam terhadap lokasi puskesmas dan sarana prasarana, maka masyarakat diharapkan mengetahui lokasi puskesmas tersebut. Sistem Informasi Geografis (SIG) merupakan salah satu teknologi informasi yang menyajikan informasi dalam bentuk peta. SIG merupakan suatu sistem berbasis komputer yang dengan kemampuan menyimpan, memanipulasi dan menganalisis data spasial dan data non spasial dapat memberikan kemudahan dalam penyajian serta pencarian informasi geografis. Untuk mengoptimalkan penyajian dan memudahkan dalam pencarian informasi lokasi dan sarana prasarana di Kabupaten Lampung Utara.

\subsection{Alat Pengembangan Sistem}




\section{A. Use Case Diagram}

Use case adalah gambaran fungsionalitas dari suatu sistem, sehingga admin atau pengguna sistem paham dan mengerti mengenai kegunaan sistem yang akan dibangun. Berikut adalah use casediagram yang diusulkan :

\section{Use Case Diagram User Umum}

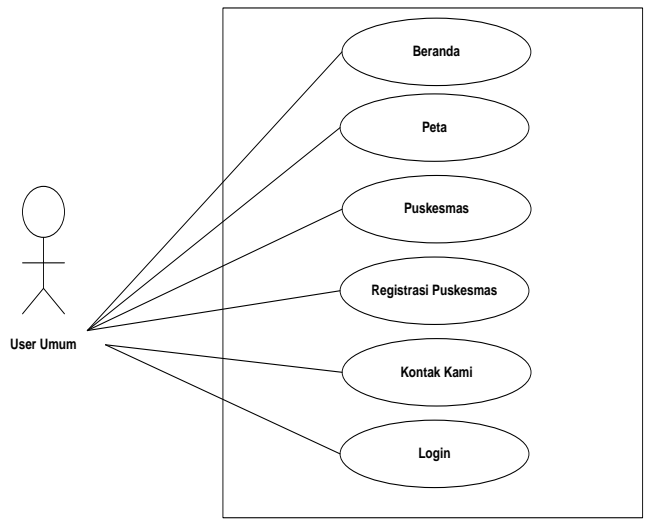

Gambar 1 Use Case Diagram User Umum

\section{Use Case Diagram Operator Puskesmas}

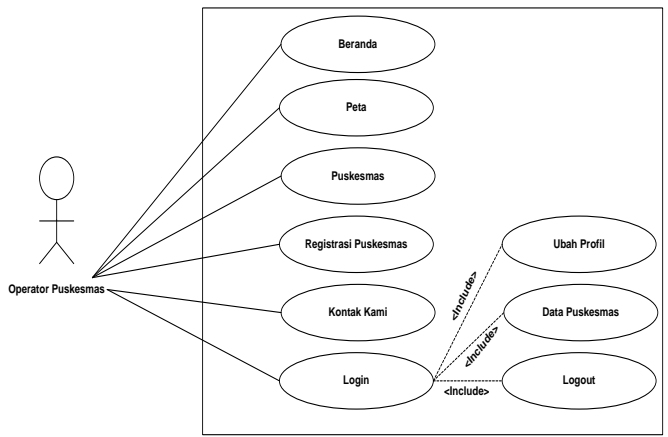

Gambar 2 Use Case Diagram Operator Puskesmas

\section{Use Case Diagram Login Operator Puskesmas}

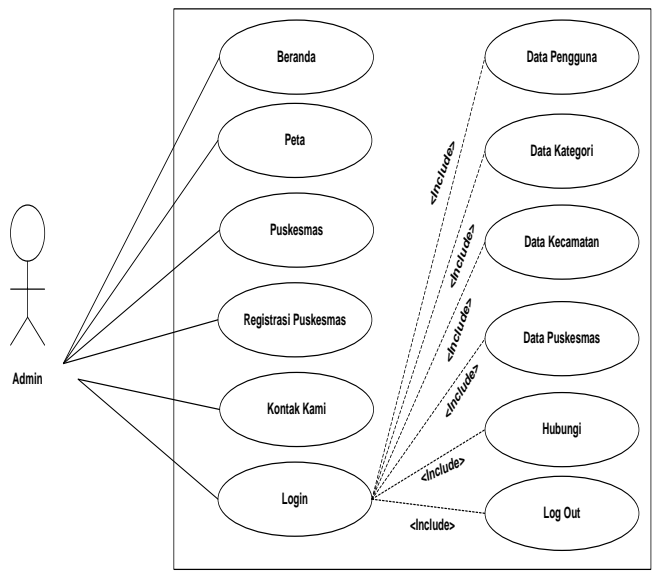

Gambar 3 Use Case Diagram Login Admin

\section{B. Activity Diagram}

Activity diagram berikut ini memperlihatkan secara rinci aliran data secara logika tanpa mempertimbangkan lingkungan fisik dimana data mengalir.

\section{Activity Diagram Admin Melihat Informasi}

Proses yang terjadi di dalam use case dari aktivitas dalam sistem yang sedang dirancang dimulai sampai dengan berhenti digambarkan dengan Activity Diagram. Activity Diagram user pada Gambar 3.2 menjelaskan proses melihat informasi tampilan awal sistem yaitu membuka aplikasi, comedian muncul halaman utama sistem yang menampilkan informasi peta.

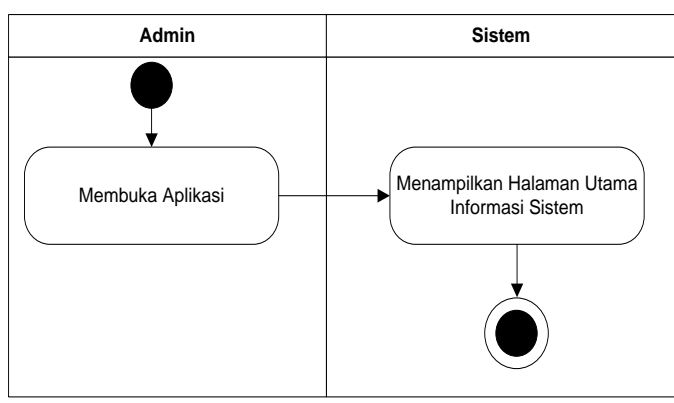

Gambar 4 Activity Diagram Admin Melihat Informasi

\section{Activity Diagram User Melihat Informasi}

Proses yang terjadi di dalam use case dari aktivitas dalam sistem yang sedang dirancang dimulai sampai dengan berhenti digambarkan 
dengan Activity Diagram. Activity Diagramadmin pada Gambar 3.3 menjelaskan proses melihat informasi tampilan awal sistem yaitu membuka aplikasi, kemudian muncul halaman utama sistem yang menampilkan informasi peta.

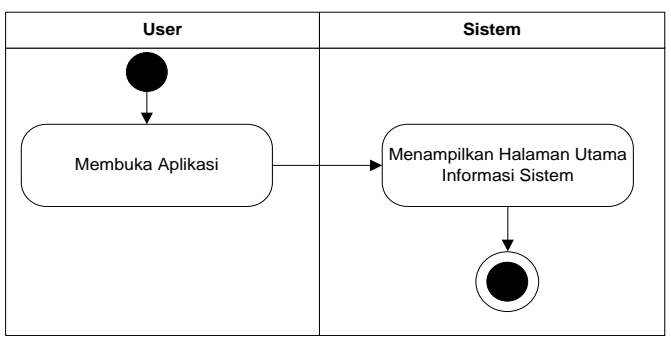

Gambar 5 Activity Diagram User Melihat Informasi

\section{Activity Diagram User Proses Search Informasi}

Activity Diagram yang menjelaskan proses search ketika pengguna ingin mengetahui lokasi puskesmas beserta sarana dan prasarananya. Pada Activity Diagram ini proses awalnya dimulai dengan pengguna membuka sistem lalu sistem menampilkan halaman utama sistem kemudian ada fasilitas search di sistem untuk memasukkan keyword pencarian nama puskesmas beserta sarana dan prasarananya kemudian langsung ditampilkan oleh sistem hasil pencarian.

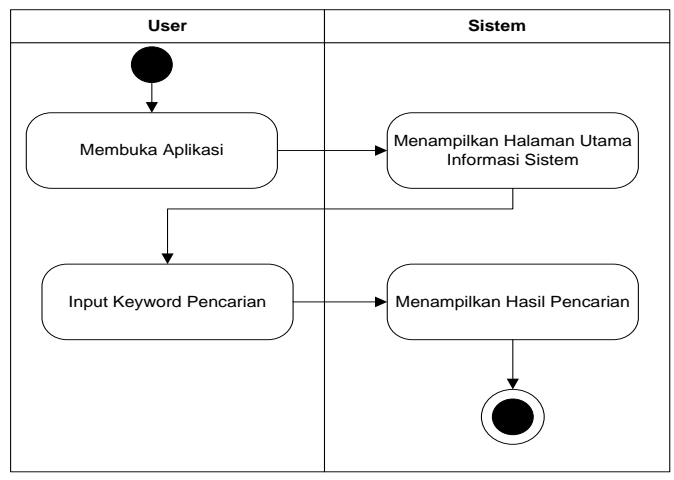

Gambar 6 Activity Diagram User Search Informasi

\section{Activity Diagram Admin Proses Mengubah Data}

Activity Diagram pada gambar 7 menjelaskan proses mengubah data dimulai dengan login yang dilakukan oleh admin dengan memberikan username atau password maka sistem akan memeriksa apakah username dan password yang masukkan benar atau salah, jika benar maka admin masuk ke dalam halaman admin jika salah kembali ke data login sebelumnya untuk konfirmasi username dan password kemudian selanjutnya proses mengubah data yang dilakukan oleh admin, pilih lihat data pada halaman utama dan sistem menampilkan data detail, selanjutnya admin dapat meng-edit data yang diinginkan, data yang diubah seperti nama, alamat, latitude dan longitude, jika sudah selesai file yang diubah kemudian simpan

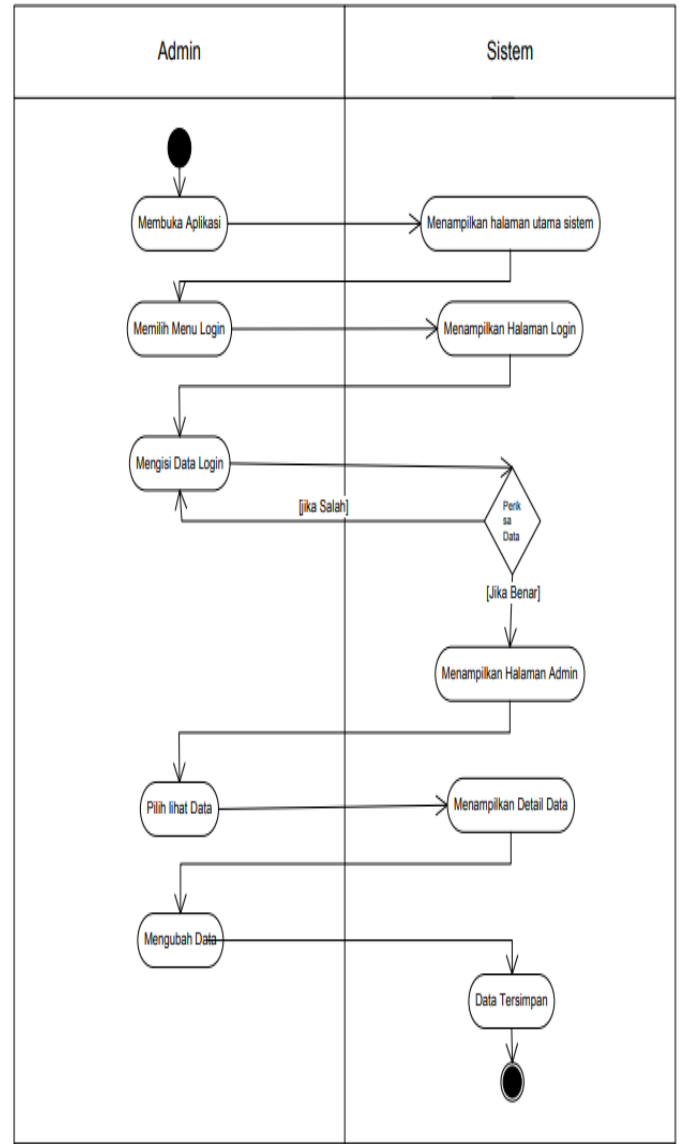

Gambar 7 Activity Diagram Admin Proses Mengubah Data

\section{Sequence Diagram}

Berikut adalah sequence diagram yang ada pada Sistem informasi geografis puskesmas beserta sarana dan prasarana berbasis web mobile di Kabupaten Lampung Utara. 


\section{Sequence Diagram Proses User Melihat Informasi}

Sequence Diagram melihat informasi sistem yang menampilkan halaman peta yang berisi titik-titik lokasi puskesmas beserta sarana dan prasarananya.

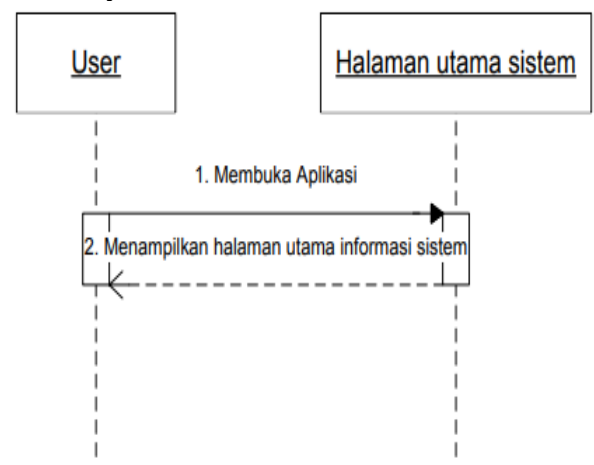

Gambar 8 Sequence Diagram User Melihat Informasi

\section{Sequence Diagram Proses Admin Melihat Informasi}

Sequence Diagram melihat informasi sistem yang menampilkan halaman peta yang berisi titik-titik lokasi Sistem informasi geografis puskesmas beserta sarana dan prasarana berbasis web mobile di Kabupaten Lampung Utara.

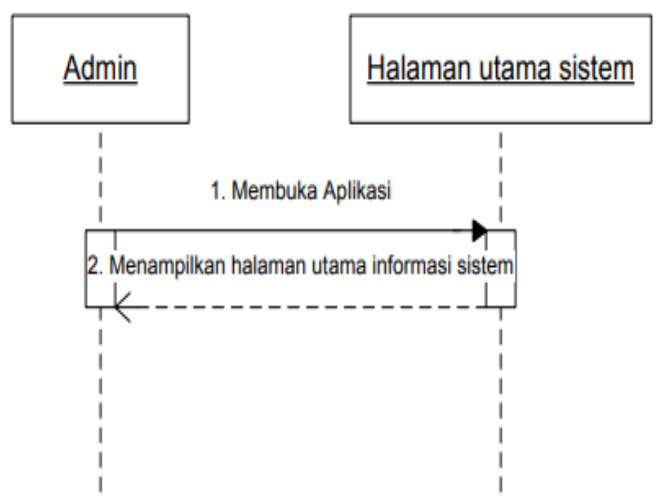

Gambar 9 Sequence Diagram Admin Melihat Informasi

\section{Sequence Diagram Proses User Search}

Sequence Diagram Proses Search yang digunakan oleh pengguna. Pengguna menggunakan Aplikasi dengan membuka aplikasi, setelah itu akan tampil halaman utama sistem, yang berisi toolbox search dengan memasukkan keyword pencarian, kemudian langsung tampil hasil pencarian di halaman pencarian.

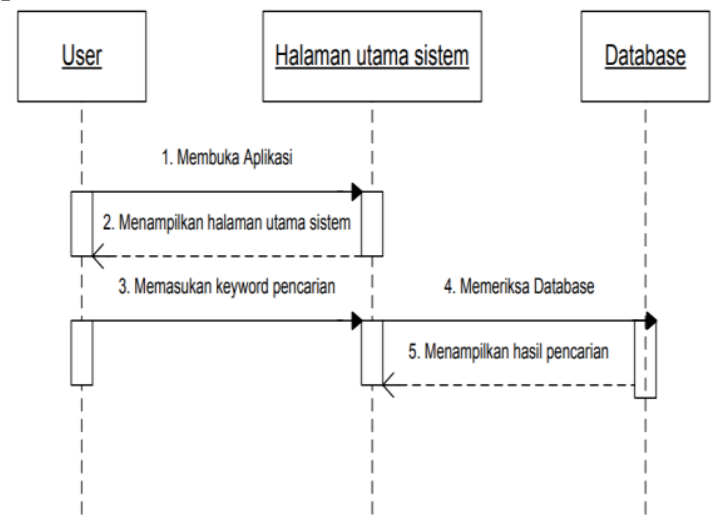

Gambar 10 Sequence Diagram Proses User Search

\section{Sequence Diagram Proses Admin Mengubah Data}

Sequence Diagram Proses mengubah data dapat dilihat pada Gambar 3.9 menjelaskan bagaimana proses berjalannya admin login sampai menampilkan halaman admin untuk mengubah data. 


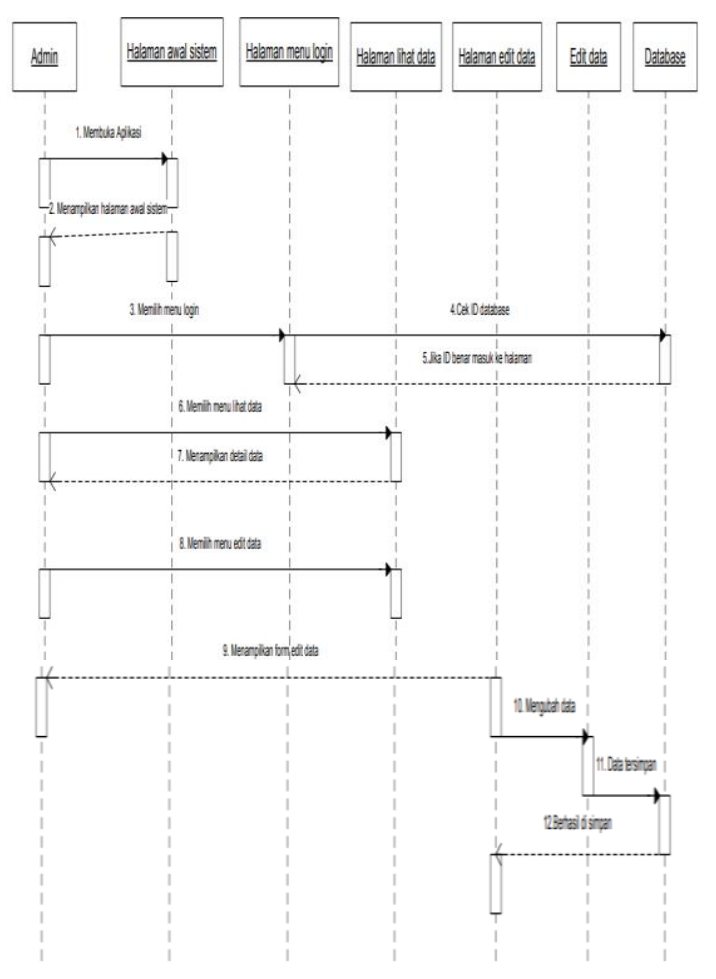

Gambar 11Sequence Diagram Proses Admin Mengubah Data

\section{HASIL DAN PEMBAHASAN}

\subsection{Hasil Program}

\subsubsection{Tampilan Home}

Pada halaman home, user dapat melihat menu peta, puskesmas, kontak kami dan login untuk user yang telah registrasi untuk menampilkan lokasi puskesmas beserta sarana dan prasarananya di Kotabumi Kabupaten Lampung Utara. Dapat dilihat pada gambar 12 berikut :

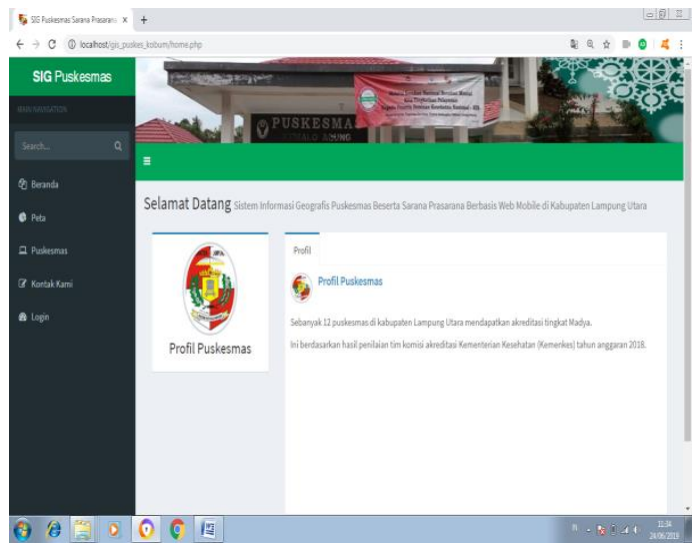

Gambar 12 Tampilan Halaman Beranda

\subsubsection{Tampilan Halaman Search}

Pada halaman ini user yang ingin melakukan pencarian lokasi puskesmas, dapat menginputkan nama puskesmas yang dicari pada textbox pencarian, setelah user mengetikkan nama puskesmas yang dicari, sistem akan menampilkan detail lokasi puskesmas beserta peta yang telah terhubung pada google maps. Dapat dilihat pada gambar 13 berikut :
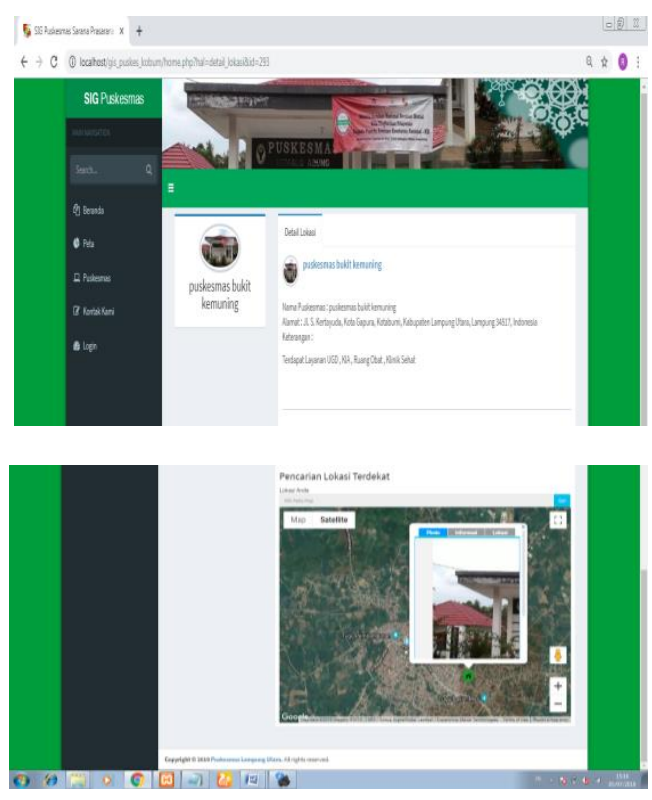

Gambar 13 Tampilan Halaman Search

\subsubsection{Tampilan Halaman Peta}


Pada halaman ini user dapat melihat peta lokasi puskesmas, admin menandai pada peta dengan titik warna hijau untuk kawasan pedesaan, titik warna merah untuk kawasan perkotaan dan titik warna kuning untuk kawasan terpencil. Dapat dilihat pada gambar 14 berikut :

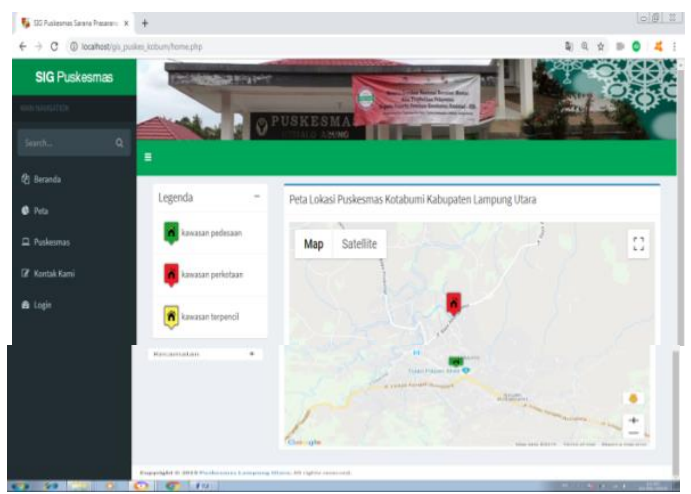

Gambar 14 Tampilan Halaman Peta

\subsubsection{Tampilan Halaman Puskesmas}

Pada halaman ini user dapat melihat daftar puskesmas yang telah terdaftar di Sistem Informasi Geografis Kotabumi Kabupaten Lampung Utara. Dapat dilihat pada gambar 15 berikut :

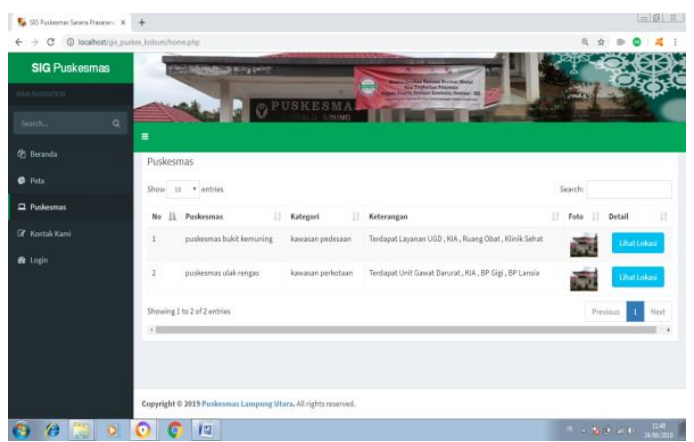

Gambar 15 Tampilan Halaman Puskesmas

Pada halaman ini user dapat mengirim pesan ke administrator, untuk mengirim pesan user dapat menginputkan field - field nama, email, subjek dan pesan. Setelah semuanya di isi user dapat mengklik tombol kirim. Dapat dilihat pada gambar 16 berikut :

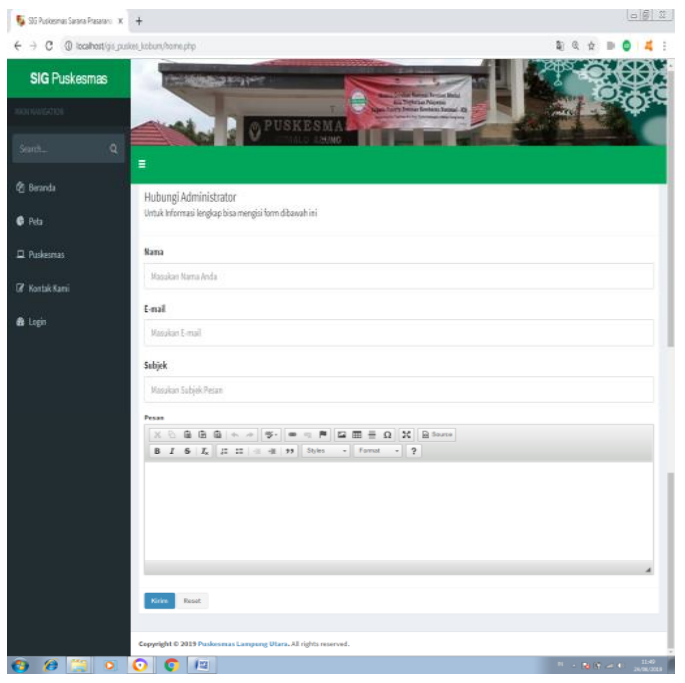

Gambar 16 Tampilan Halaman Kontak Kami

\subsubsection{Tampilan Halaman Login Admin}

Pada halaman ini untuk masuk kehalaman admin, admin harus terlebih dahulu masuk kehalaman login admin dengan memasukkan username dan password, jika username dan password benar maka admin akan masuk kehalaman admin, jika username dan password salah maka akan muncul pemberitahuan bahwa username dan password salah. Dapat dilihat pada gambar 17 berikut :

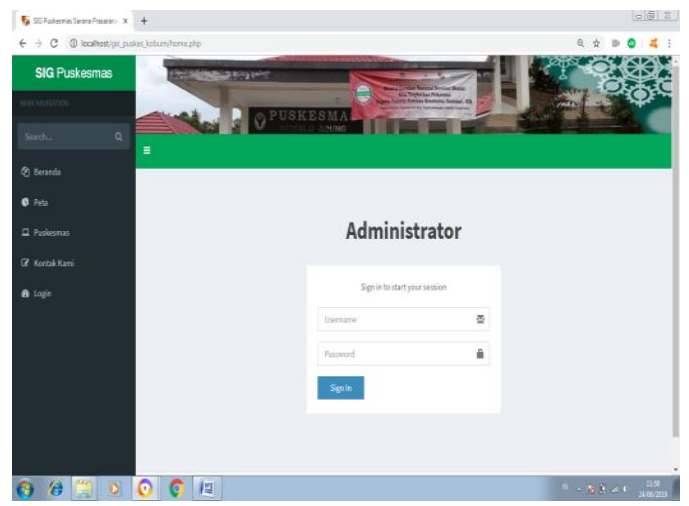

Gambar 17 Tampilan Halaman Login Admin

\subsubsection{Tampilan Halaman Home Admin}

Pada halaman ini admin dapat mengakses menu - menu admin seperti profil, data pengguna, data kategori, data kecamatan, data puskesmas dan logout. Dapat dilihat pada gambar 18 berikut : 


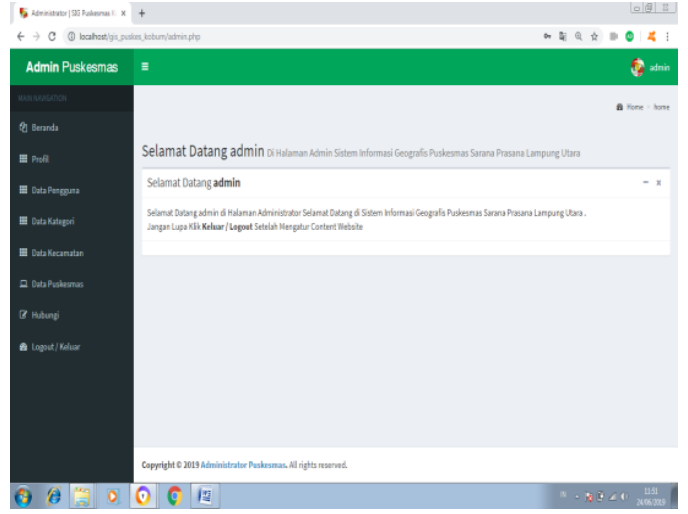

Gambar 18 Tampilan Halaman Home Admin

\subsubsection{Tampilan Halaman Tambah Data Pengguna}

Pada halaman ini admin dapat menambahkan data pengguna dengan cara menginputkan field - field yaitu username, password, nama lengkap dan email pengguna baru. Setelah semua field field terisi admin dapat mengklik tombol simpan. Dapat dilihat pada gambar 19 berikut :

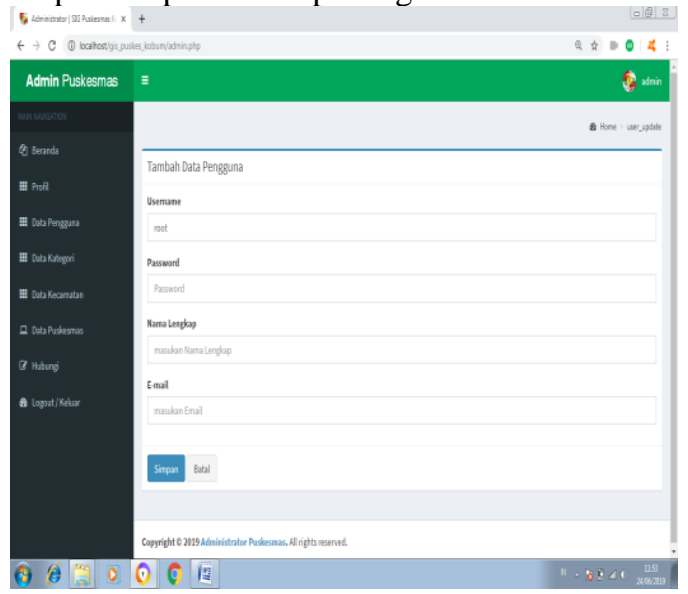

Gambar 19 Tampilan Halaman Data Pengguna

\subsubsection{Tampilan Halaman Tambah Kategori Puskesmas}

Pada halaman ini admin dapat menambahkan data kategori puskesmas dengan cara menginputkan field - field yaitu nama kategori dan mengupload icon peta. Setelah semua field - field terisi admin dapat mengklik tombol simpan. Dapat dilihat pada gambar 20 berikut :

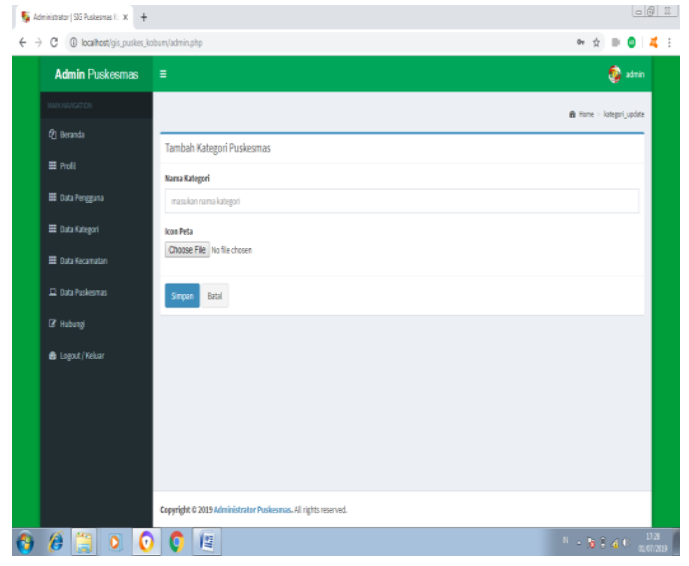

Gambar 20 Tampilan Halaman Kategori Puskesmas

\subsubsection{Tampilan Halaman Tambah Data Kecamatan}

Pada halaman ini admin dapat menambahkan data kategori puskesmas dengan cara menginputkan field - field yaitu nama kecamatan. Setelah semua field - field terisi admin dapat mengklik tombol simpan. Dapat dilihat pada gambar 21 berikut :

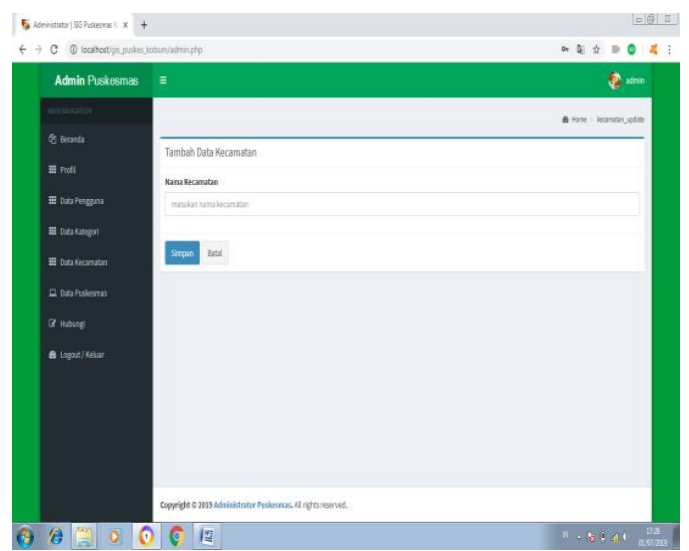

Gambar 21 Tampilan Halaman Tambah Data Kecamatan

\subsubsection{Tampilan Halaman Data Puskesmas}

Pada halaman ini admin dapat menambahkan data puskesmas dengan cara menginputkan field - field yaitu puskesmas, pilih kecamatan, pilih kategori, sarana dan prasarana, field koordinat dan alamat akan terisi otomatis ketika admin memilih lokasi pada peta dan admin dapat 
mengupload foto lokasi. Setelah semua field field terisi admin dapat mengklik tombol simpan. Dapat dilihat pada gambar 22 berikut :

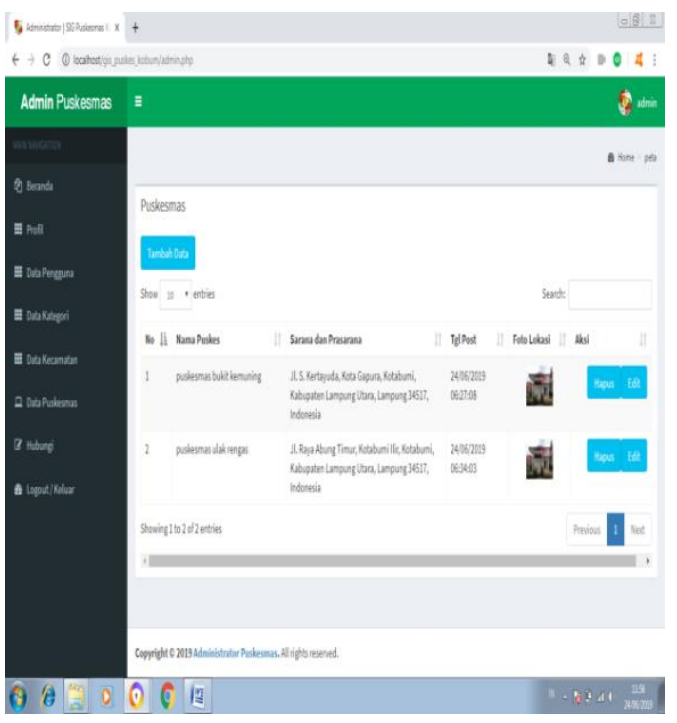

Gambar 22 Tampilan Halaman Data Puskesmas

\subsubsection{Tampilan Halaman Hubungi Kami}

Pada halaman ini, admin dapat melihat pesan masuk dari user atau masyarakat Lampung Utara, admin juga dapat membalas pesan masuk yang akan terkirim ke email user yang telah menghubungi admin. Dapat dilihat pada gambar 23 berikut :

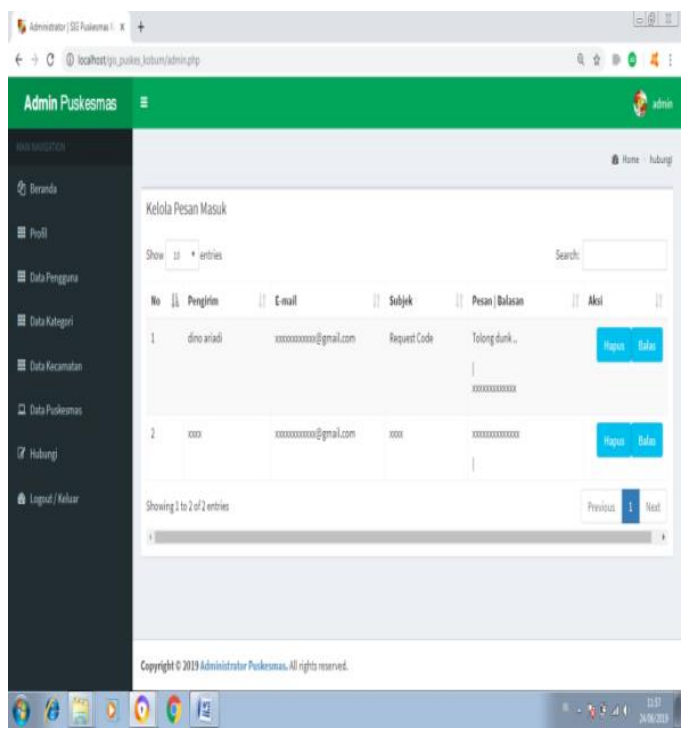

Gambar 23 Tampilan Halaman Hubungi Kami 4. PENUTUP
Berdasarkan hasil penelitian sampai pengujian sistem maka dapat diambil beberapa kesimpulan, yaitu :

1. Dengan adanya Sistem informasi geografis puskesmas beserta sarana dan prasarana berbasis web mobile di Kabupaten Lampung Utara memberikan kemudahan informasi lokasi puskesmas beserta sarana prasarana yang ada di Kotabumi Kabupaten Lampung Utara.

2. Dengan adanya Sistem informasi geografis puskesmas beserta sarana dan prasarana berbasis web mobile di Kabupaten Lampung Utara pihak Puskesmas yang ada di Kabupaten Lampung Utara telah menerapkan teknologi berbasis web mobile dalam mengelola informasi lokasi Geografis.

3. Dengan adanya sistem ini dapat memudahkan pengguna dalam pencarian lokasi puskesmas dan mengetahui sarana dan prasarananya di wilayah Lampung Utara.

\section{DAFTAR PUSTAKA}

[1] A. Sumardin, Arfandi S. Penerapan Sistem Informasi Geografis Dalam Pemetaan Produksi Pertanian di Kabupaten Bone, Sulawesi. (2016)

[2] Rizki Wahyudi, Tri Astuti.. Sistem Informasi Geografis (SIG) Pemetaan Bencana Alam Kabupaten Banyumas Berbasis Web, Jawa Tengah. (2016)

[3] Afif Luthfi. Pengembangan Prototipe Sistem Informasi Geografis Penyebaran Rute Angkutan Umum Kota Semarang. (2016)

[4] Reni Astika. Sistem Informasi Geografis Pemetaan Lokasi Bank Rakyat Indonesia (BRI) di Bandar Lampung, Lampung. (2017)

[5] Dwi Marisa Effendi, Joni Darsyah. Sistem Informasi Geografis Lokasi Kost dan Penginapan Berbasis Web Pada Wilayah Kotabumi 
Kabupaten Lampung Utara. Lampung. (2018)

[6] Azrul Azwar. Pengantar Administrasi Kesehatan. Edisi Ketiga. Jakarta : Binarupa. Aksara. (2013)

[7] Sadeli, Muhammad. Macromedia Dreamweaver Untuk Orang Awam. Palembang:Maxikom. (2016)

[8] Sharp, H., Giuffrida, R. and Melnik, G. Information Flow within A Dispersed Agile Team: A Distributed Cognition Perspective. Agile Processes in Software Engineering and Extreme Programming. (2015)

[9] Safaat, N., Pemrograman Aplikasi Mobile Smartphone dan Tablet PC Berbasis Android, Informatika, Bandung. (2016)

[10] Sugiri dan Kurniawan Budi. Desain Web Menggunkan HTML dan CSS, Andi, Yogyakarta. (2017)
[11] Kadir, A., Membuat Aplikasi Web dengan PHP dan Basisdata MySql, ANDI, Yogyakarta. (2016)

[12] Kustiyaningsih, Yeni "Pemrograman Basis Data Berbasis Web Menggunakan PHP \& MySQL". Graha Ilmu, Jakarta (2015)

[13] Rosa AS dan M.Shalahuddin.. Rekayasa Perangkat Lunak Terstruktur Dan Berorientasi Objek. Bandung : INFORMATIKA. (2015)

[14] Ludwig Von Bartalanfy. Pengertian Sistem (2015)

[15] Pengertian Sistem Menurut Jogianto (2005: 2)

[16] Menurut Bodnar dan Hopwood. Pengertian Sistem Informasi (2013)

[17] Pengertian Sistem. Tata Sutabri, S.Kom., MM, 2005:36) 